\title{
Geopolitical Imagination: Ideology and Utopia in Post-Soviet Russia
}

\author{
Mikhail Suslov \\ Stuttgart: ibidem 2020 \\ 289 sider. ISBN: 139783838213613
}

Omtalt av Iver B. Neumann [direktør, Fridtjof Nansens Institutt, Lysaker, Norge, ibneumann@fni.no]

De gamle grekere grunnla geografien som en hjelpedisiplin for strategisk tenkning, og romerne videreutviklet geografien innen den samme rammen. Det geografiske vokabularet vi bruker den dag i dag, er altså ikke "militarisert», for det har alltid vært militært. Det skandinaviske «region» er for eksempel en etymologisk frukt av det latinske verbet regere, og betyr altså opprinnelig det som skal undertvinges og styres. Fra slutten av 1800-tallet av vokste det spesielt i Tyskland, Storbritannia og USA frem en "geopolitikk», der prosjektet var å tenke omkring roms betydning for politikk. En av geopolitikkens grunnleggere var svensken Rudolf Kjellén, som tenkte omkring staten som en levende organisme, bundet til jordsmonnet. Denne type tenkning var populær før, under og efter første verdenskrig, men fikk et tilsynelatende dødsstøt da den ble omfavnet av nazistene. Blottet for sine organiske elementer holdt den imidlertid stand i militære og enkelte politiske kretser gjennom hele den kalde krigen (Henry Kissinger var fan).

Da den kalde krigen tok slutt og Russland ble stående igjen uten noen ideologi som kunne erstatte kommunismen som grunnlag for sosial og politisk tenkning, dukket organisk geopolitikk igjen opp. Det kunne den gjøre fordi noen få ildsjeler, med Lev Gumilev i spissen, hadde utviklet den organiske geopolitikken til et spesifikt russisk begrepsapparat. Sentralt hos Gumilev står begrepet passionarnost', et begrep som nettopp skal dekke selve grunnideen i organisk geopolitikk, nemlig at det finnes et bånd mellom jordsmonnet og menneskene som lever på det, som gjør at geografien på mystisk vis beånder sine innbyggere. Mark Bassin, som har skrevet forordet til Suslovs bok, skrev for et par år siden sin egen bok om Gumilev og hvordan han klarte å klekke ut og spre sine geopolitiske tanker i kanten av et ambivalent Sovjet regime.

Suslov fortsetter der Bassin sluttet, med hvordan publisister som Aleksandr Dugin, Vadim Tsimburskij og en rekke andre fortsatte å utvikle russisk organisk geopolitisk tenkning der Gumilev sluttet. Første kapittel av boken er en oversiktsartikkel, 
der Suslov diskuterer geografiens ontiske status. For ham, som for Bassin og andre såkalte kritiske geopolitikere, er geografi nettopp ikke «organisk», men derimot sosialt konstruert. Når vi orienterer kirker øst-vest, snur oss mot Mekka når vi ber, tegner et kart eller tenker på Frankrike som en femkant, forstår og ordner vi geografien sosialt. Geografi er altså sosialt konstruert. Suslov insisterer på å se Dugin, Tsimburskij og de andre som fullt bevisste, politiske aktører som bruker geografien på samme måte som Lenin sa kommunistene skulle bruke historien: som en hammer. «[G]eopolitical imagination serves as 'pre-propaganda', preparing and conditioning the audience into accepting a specific political move as a natural and reasonable thing», som Suslov presist uttrykker det på side 22. For Suslov er det slik at de spatiale identitetene han studerer er blitt viktigere enn de temporale. Det trenger vi neppe ta stilling til, for historier om hvem «vi» er, både i tid og rom, vil per definisjon være viktige for identitetspolitikken.

De påfølgende kapitlene trekker på dette perspektivet. Kapittel to gir en oversikt over såkalte lærebøker om geopolitikk og hvordan de brukes. Suslov presiserer at forfatterne ofte ikke er akademikere, men at bøkene deres like fullt brukes ved universiteter i stor skala. Kapittel tre dekker russiske sivilisasjonsdebatter, for sivilisasjoner har jo, som alle andre forestilte geopolitiske prosjekter, en spatial utbredelse og grensesoner. Kapittel fire, som for meg var bokens høydepunkt, dekker det geografiske aspektet av russisk science fiction. Det publiseres 400 til 600 romaner i året. Der science fiction under den kalde krigen var liberale dissidenters domene, er den i dag blitt "pulp fiction aimed at the grassroots» skriver Suslov (side 148), og legger til at «a typical SF writer is an intellectual proletarian, whose literary production reflects his or her declassé social position» (side 152). Man kan også legge til at kinesisk science fiction er sterkt nasjonalistisk, og at det i USA i flere år nå har pågått en kulturkamp der liberale og nasjonalister tørner sammen når det skal massestemmes over hvilke bøker som skal få Hugo- og Nebula-prisene. Kampen om genrens sjel synes å være internasjonal.

Kapittel fem diskuterer Det hellige Rus'. Her er det lite nytt, ikke minst fordi ibidem forlag ikke synes å ha redigert boken noe særlig, ei heller gjort Suslov oppmerksom på Jardar Østbøs flotte utgivelse om akkurat dette temaet på samme forlag. Kapittel seks dekker eurasianistene, men igjen er det lite nytt for den som kjenner Marlene Laruelles og Bassins produksjon om temaet. Kapittel syv er en fin gjennomgang av Igor' Alimov og Vjatsjeslav Rybakovs syvbinds romansyklus om Ordus'. Denne alternative virkeligheten, som er skapt av to russiske sinologer som forutsetter at Rus' og Den gyldne horde (Zolotaja Orda) ble en statsdannelse som Kina i sin tur sluttet seg til, er selvfølgelig gefundenes fressen for en kritisk geopolitiker. Kapittel syv er en overbevisende gjennomgang av geopolitikere og politikeres forsøk på å skape et historisk «Novorossija» som legitimering for en fremtidig russisk overtagelse av Donbass og omegn. Novorossija ble opprettet som et gubernija av Katarina den store i 1764 efter hennes invasjon av området, og besto til 1802. Novorossijsk er også navnet på en by i Krasnodar. Suslov argumenterer overbevisende for at forsøket på 
å gjøre det til en organisk enhet feilet både av identitetspolitiske grunner (det viste seg umulig å gi det grenser og å få folk til å mobilisere noen følelser for det) og mer spesifikke lingvistiske grunner (man kunne ikke få knesatt et navn på folk som kom derfra).

De to kapitlene om russisk science fiction og kapitlet om Novorossija er sterke, og giør at denne utgivelsen forsvarer sin plass. Gitt at Suslovs objekt er den russiske forestillingsverden, som Cornelius Castoriadis i sin tid kalte det, er det en klar styrke at Suslov jobber med ideer på tvers av forskjellige genrer. De russiske ideene som diskuteres, er ofte naive og hjelpeløse. Det var med god grunn at den type organisk geopolitikk som nå får blomstre i Russland, ble og forblir sterkt marginalisert i Vesten. Det dreier seg om politisk tenkning på mystiske og derfor akademisk uholdbare forutsetninger. Et økonomisk perspektiv mangler helt. Det er interessant, for det som finnes av geopolitisk tenkning i Vesten i dag, er stort sett såkalt geoøkonomisk tenkning, gjerne rettet inn mot bygging av infrastruktur (oljeledninger, havner, belt and road, den nordlige siørute etc.) Kan dette skyldes at Russland gjemmer seg $i$ en tenkning som helt ser bort fra det området der Russland er svakest, nemlig økonomien? Resultatet er i alle fall at det meste av denne tenkningen, om Russland som et hav, en øy, en bastion og så videre, minner mistenkelig om Hamlets grublerier:

$\begin{array}{ll}\text { Hamlet: } & \text { Do you see yonder cloud that's almost in shape of a camel? } \\ \text { Polonius: } & \text { By the mass, and 'tis like a camel, indeed. } \\ \text { Hamlet: } & \text { Methinks it is like a weasel. } \\ \text { Polonius: } & \text { It is backed like a weasel. } \\ \text { Hamlet: } & \text { Or like a whale? } \\ \text { Polonius: } & \text { Very like a whale. }\end{array}$

Vi må imidlertid gå ut fra at den russiske forestillingsverdenen, i motsetning til én manns grublerier, til enhver tid foregår innen et spektrum som er sosialt gitt, for uten en viss sosial regularitet i hva som blir sagt, kan man ikke oppebære en nasjonal samtale. Et system av forutsetninger for å kunne fremsette sannhetskrav, kaller man en diskurs. Suslov lykkes i å nøste opp en spesifikk diskurs i kapitlet om Novorossija, men han får ikke til det samme hva hele den russiske geografiske forestillingsverdenen angår. Denne boken blir dermed en artikkelsamling med en kappe over, snarere enn et integrert hele. 